\title{
Improving Collaborative Work between Gastroenterology Ward and Drug and Alcohol Addiction Rehabilitation Service
}

1 Iva Ričko

1 Emergency Department, Royal Berkshire NHS Foundation Trust, Reading, United Kingdom

Article received: 04.07.2018.

Article accepted: 27.11.2018.

Author for correspondence:

Iva Ričko

Emergency Department, Royal Berkshire NHS Foundation

Trust

London Road, Reading RG1 5AN

United Kingdom

E-mail: iva.ricko@royalberkshire.nhs.uk

Dol: $10.24141 / 2 / 2 / 2 / 8$

Keywords: leadership, physiotherapy, gastroenterology ward, drug and alcohol community services

\section{Abstract}

Introduction. The need for developing this project was identified while working with multidisciplinary team at the Royal Berkshire Hospital in England, where it was apparent that healthcare professionals faced issues of providing continuous rehabilitation before and after discharging patients with drug and alcohol addiction from hospital.

Aim. To ensure that all team members on Gastroenterology Ward - occupational therapists, physiotherapists, nurses and therapy assistants - are competent to refer patients into the Community Drug and Alcohol Rehabilitation Centre - Integrating Recovery in Service ( $\left.{ }^{*} I R I S\right)$; therefore improving collaboration with IRIS.

Methods. An initial study was conducted at the Royal Berkshire Hospital in England, between October and December 2017, while the evaluation study was conducted in the period between February and March 2017, on a sample of 20 respondents. The data was collected by means of a questionnaire which was created for the purposes of this study.

Results. After the analysis of the evaluation study results, $85 \%$ of the respondents considered that communication between the services improved, while $65 \%$ of the respondents attended the workshops and trainings organised by IRIS. Statistical significance $(p<0.05)$ was not observed in referring patients to IRIS ( $p=0.055$ ), this could be due to a small sample of respondents.

Conclusion. Team integration is key to implementing collaborative guidelines. The implementation of changes was based on increase in communication, organising trainings and further education, and referring patients to IRIS. Improvement in all categories greatly contributed to the increase in the competences of team members on the ward.

\footnotetext{
* IRIS - Integrated Recovery in Service
} 


\section{Introduction}

Leadership in a multi-disciplinary team is inspired by the theory of system complexity, which recognises that every change occurs naturally within the institution (1). Good practice will expand faster through healthcare facilities if healthcare leaders follow the guidelines for making changes. One of the roles of a good leader is to devise a way of keeping good practice within the team (2).

Teams in health care need to start the process of change independently. For this purpose, it is possible to use the organisational capabilities of team members to develop professional relationships, regardless of the professional role (3).

\section{Collaboration in healthcare}

American surgeon and writer Atul Gawande identified that we currently live in a "century of systems" in which individuals and organisations cannot solve the problems they face alone (4). Gawande suggests designing new ways of team collaboration, through organisational systems, so that collective skills and knowledge are directed and exploited in the best way (4). National and international leaders are trying to achieve collaboration within and outside healthcare institutions (5). It is arguable that the main foundation of leadership is the mutual sharing of knowledge and information (5). Noticeable changes are made by developing new models and transformational plans (6). Leaders in health care are facing the demand for collaboration due to market changes and local competition. It should be stated that healthcare institutions are under great financial pressure (7). An example of governance development and collaboration between local authorities in Manchester and the United Kingdom National Health System, with the aim of long-term collaboration is described by Fillingham and Weir in a case study entitled "Living Better means Living Longer" (8). The idea was to create a multi-agency group with eight experienced healthcare managers who were due to work on a community development project. This group acted as a driver for new ideas and approaches to health management and leadership. Collaboration between healthcare institutions and community organisations has been improved, which has contributed to the development of new short-term and long-term programmes and projects in various health organisations (9). One of the great examples of collaboration is described through the experience of the Canterbury County Healthcare Clinic in New Zealand, which was facing problems of growing and aging populations (10). The members of the clinic and board leaders had to work together through the framework called "One System and One Budget" even though it was not just a single system or just one budget issue. In this case, the National Health Committee was a catalyst for regulating the work of clinicians, managers and other associates in organisational planning through an exhaustive process of collaboration between the services and the community. Final agreement was reached and based on a common vision in which patients had the main role. Hospital reconstruction, reduced hospital stays and investment in rehabilitation have been successfully implemented. None of the above would been possible if all participants had not worked together towards the same goal (10).

\section{Clinical leadership programme}

Healthcare professionals have the possibility of further training and education through various programs and workshops (11). Prior to developing any hospital and community-based projects, healthcare professionals attend the Clinical Leadership Program. This programme is created for professionals with various clinical experience and team leaders that want to expand knowledge and understanding of certain leadership styles. The United Kingdom Health Care Academy in collaboration with Hay Group and Open University has developed 9 Dimensions of Health Care Management Model (12). This model is based on evidence of secondary research conducted between March and April 2013 and primary research carried out between April and June 2013, reflecting the principles of health organisations, knowledge of health management, patient and community requirements (13).

The leadership model used during the development of this project is the ADKAR model (Awareness, Desire, Knowledge, Ability, Reinforcement), which is most commonly used when it is necessary to establish collaboration with community services. This model of change is a practical solution to the effective change that individuals and organisations can apply. It is useful to use and easy to learn. The model is based on the assumption that change is only successful once each individual within the organisations has succeeded in adjusting to that particular change (14). 
As part of the Clinical Leadership Program, all participants must devise an innovative project that will contribute to the development of the institution they work in and use knowledge of various styles and leadership models. It is well-known that innovation alone can raise healthcare organisations to a higher level through coping with radical changes (15). Innovation is defined as the absolute novelty introduced into procedures and treatments, new teams introduced into existing teams and new frameworks that benefit patients, staff, organisations and the wider society (16).

\section{Standardized self-assessment of management and leadership}

The self-assessment was created for the purpose of assessing self-consciousness within the working environment. Results provide an insight into the current level of performance at the workplace. Self-assessment is based on 9 dimensions of team management through a model of management in health care (17). Self-assessment is a useful way of examining behaviours of healthcare professionals during project development. The ideal result should emphasise a high level of task performance closely related to the current role of a healthcare professional in the team. Healthcare professionals use this kind of self-assessment before starting new projects within the working environment and often as an evaluation after the implementation and completion of the project.

\section{Launching the project}

After investigation of rehabilitation facilities and community centres, it was concluded that the Royal Berkshire Gastroenterology Ward did not possess the necessary information about the relevant centres and thus could not apply a holistic approach to treatment and further rehabilitation. The department was lacking relevant leaflets, posters, information packages, and referrals that are essential to educating and supporting patients before discharge from hospital. Prior to the development of the project, it was necessary to check whether community health organisations are ready for change and if they support the change.

\section{Finding partners for collaboration}

When preparing an innovative project, it is necessary to find partners who are willing to collaborate. This may be someone completely new or even a partner with which a different kind of collaboration has been achieved in the past (18). Collaboration is defined through a shared vision, an ambition towards achieving the same goal, implementing joint leadership styles and shared responsibility for accountability (19). Examples of successful collaboration can often be demonstrated through the role of experts in various healthcare structures. The main partner when developing this project was the Community Drug and Alcohol Rehabilitation Centre - Integrating Recovery in Service (IRIS). Frequent meetings with the manager of IRIS were of utmost importance for the success of the project. Meetings have proven to be crucial when making decisions and developing guidelines for referring patients to IRIS as well as for developing long-term collaboration.

\section{Community Drug and Alcohol Rehabilitation Centre - Integrating Recovery in Service (IRIS)}

The centre is accessible to people over the age of 18, living outside the West London area. The Royal Berkshire Hospital had collaborated with IRIS in the past, but the collaboration was not very successful. Services provided by the IRIS are available to patients with drug and alcohol addiction and their families. IRIS promotes flexibility and the ability to change (20). The rehabilitation process begins with an initial assessment with the aim to identify current problems and causes of addiction. After assessing patient's needs, the team of professionals creates an individual plan, and sets short-term and long-term goals for every patient. Patients are not expected to go through the process alone, so they are given support from professionals and peers (21). Patients who have successfully passed the key aspects of the initial program go to the next stage called the abstinence program (21). This program is specifically designed for patients who are trying to reintegrate into the society. The program provides assistance with job search, further education, volunteering and also provides mentoring opportunities for patients who are at the beginning of a rehabilitation program by patients who have successfully completed their program in the past (21).

\section{Implementing the change}

The changes that were integrated after processing the data of the initial questionnaire were carefully analysed at expert meetings with the managers at IRIS. 
Collaboration with the General Education Team within the hospital and the Educational Team at IRIS was established. The hospital in-service training team arranged dates for future workshops and lectures for a period of 6 months that will be available to staff monthIy. Managers at IRIS had voluntarily agreed that the lectures will be held by their associates and lecturers. Guidelines needed to be developed to improve communication with IRIS. A poster with guidelines and essential contacts was designed to facilitate and speed up communication with IRIS. Posters were placed in visible areas in the department, in this case behind the reception area and close to the entrance door. Ward manager had named the contact person who will be responsible for future direct communication with managers at IRIS in the event of a lack of information and promotional material on the ward.

\section{Methods}

Initial research was conducted in England, on Gastroenterology Ward at the Royal Berkshire Hospital in the period between October and December 2017. The study was conducted with the help of a questionnaire composed of 7 questions. The questionnaire was created and conducted for the purpose of examining the quality of communication between the ward and the Community Rehabilitation Centre (IRIS), the relevant community education resources, and the methods and knowledge about referring patients with drug and alcohol addiction to community rehabilitation service. The questionnaire was filled out anonymously by physiotherapists, nurses and therapy assistants on the Gastroenterology Ward. The questionnaire was placed at the reception desk so that it was visually noticeable. Participation in the interview was supported by the head of department who verbally encouraged staff to fill in questionnaires on occasions when therapists were not present on the ward.

Initial survey included 16 nurses, 3 therapy assistants and 1 physiotherapist (Graph 1). Difficulties in conducting initial research were most often related to the absence of staff due to frequent annual leave and sickness during the period of research. The evaluation, i.e. the final survey, was conducted in the period from February to March 2018 on the Gastroenterology Ward at Royal Berkshire Hospital. It was conducted with the help of a 6 -question questionnaire that was used to compare and detect changes on the ward through the implementation of innovations in communication, education and referral pathway. The final survey was conducted anonymously on a sample of 20 respondents: physiotherapists, occupational therapists, nurses and therapy assistants.

The evaluation questionnaire was placed at the reception desk, in the same place as the initial questionnaire for the sake of easier detection. Respondents involved 14 nurses, 4 therapists (physiotherapist and occupational therapist) and 2 therapy assistants (Graph 2) during the evaluation study.

The expressed parameters after the research collected from the initial and evaluation questionnaire were turned into percentages and graphically compared with parameters from the first and second group of respondents. The statistically significant difference in patient referral categories to the Rehabilitation Centre (IRIS) was calculated using Fisher's exact probability test. The test is otherwise demanding to compute so it is good for smaller samples $(<100)$.

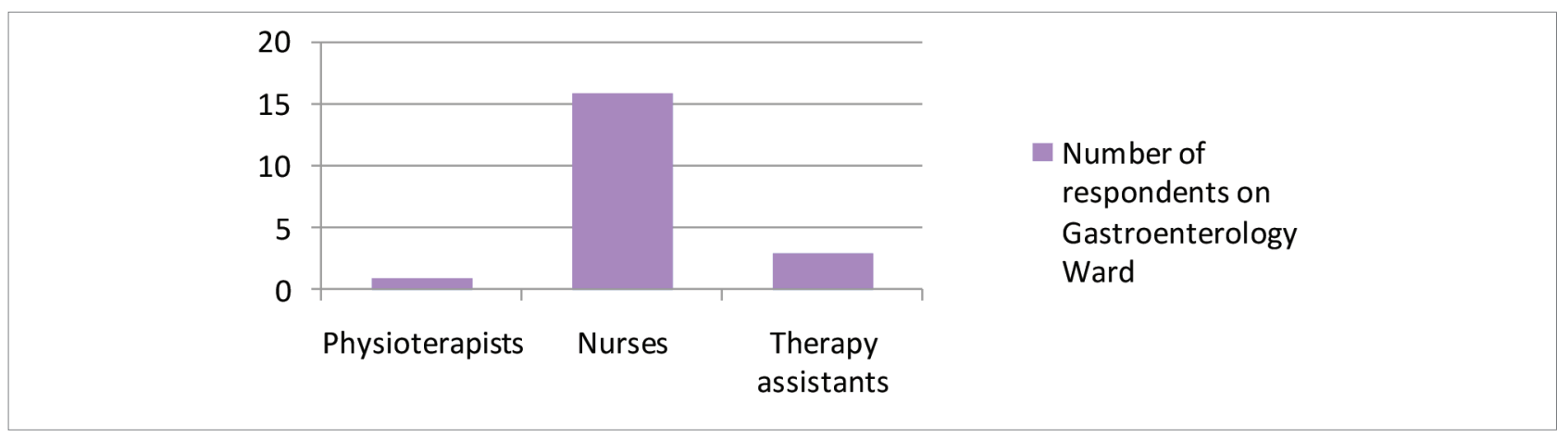




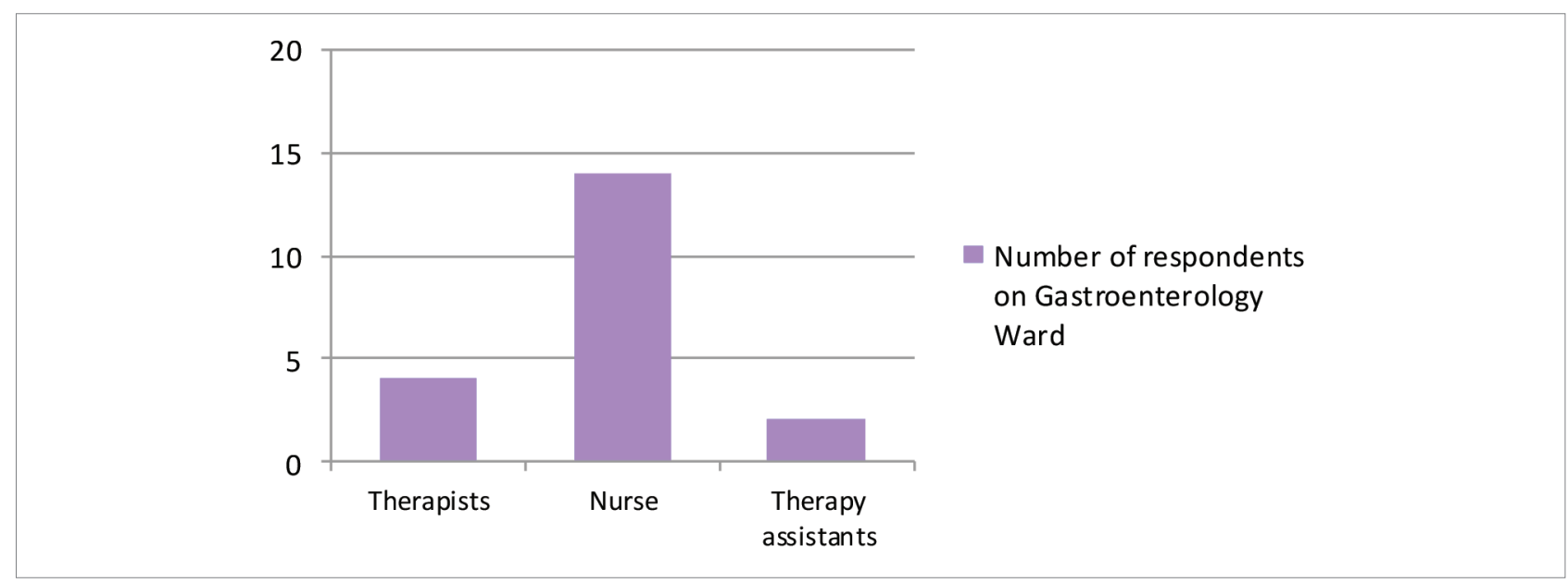

Graph 2. Distribution and number of respondents in the evaluation study

\section{Results}

The results obtained after the statistical analysis of the initial and the evaluation questionnaire were analysed by individual questions of the questionnaire. Questions that had shown a significant difference in the initial and evaluation research are separated and presented graphically.

\section{Initial survey}

Graph 3 demonstrated that $80 \%$ of the respondents had stated that they did not have necessary education on drug and rehabilitation centre in the community, while $20 \%$ of the respondents claim that they were provided relevant education.

Graph 4 demonstrates that 55\% of the respondents believe that the department has the necessary leaf- lets and information packages on drug and alcohol addiction rehabilitation centres, while $45 \%$ of the respondents believe that the department does not possess the necessary information packages.

Graph 5 demonstrates that $85 \%$ of the respondents believe that they do not have access to training on drug and alcohol addiction, while $15 \%$ believe that access to relevant education on drug and alcohol addiction is enabled.

Graph 6 demonstrates that $70 \%$ of the respondents do not refer patients to the Drugs and Alcohol addiction Rehabilitation Centre. Only 30\% of the respondents independently refer patients to the Drugs and Alcohol addiction Rehabilitation Centre.

\section{Evaluation survey}

The aim of the final research is to evaluate the applied changes and to identify still present problems.

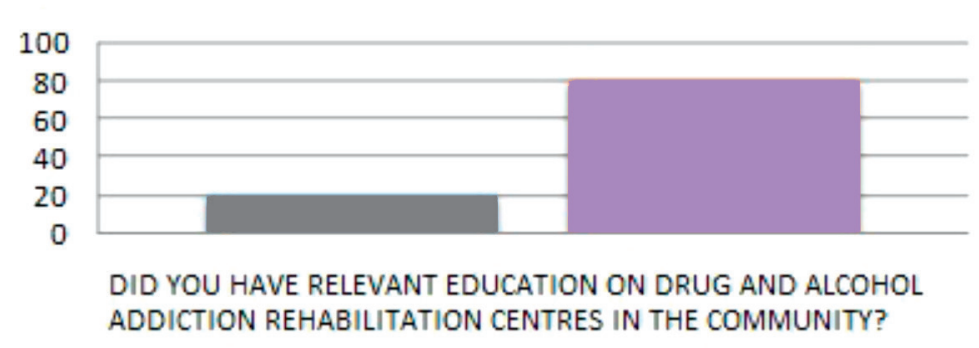




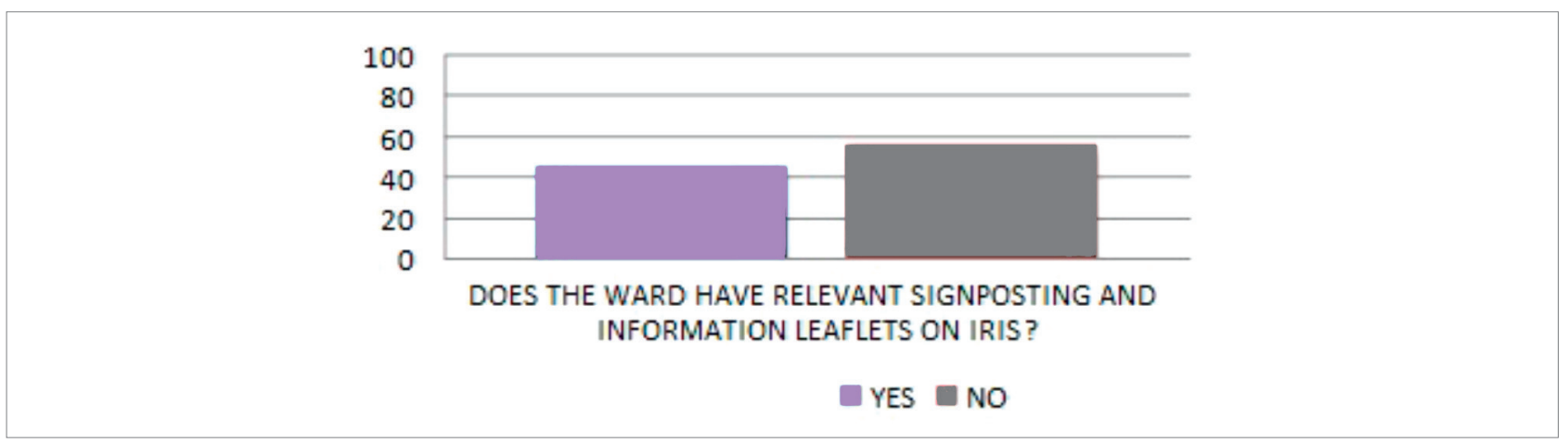

Graph 4. Data relating to the question regarding relevant signposting on the ward in percentages $(\mathrm{N}=20)$

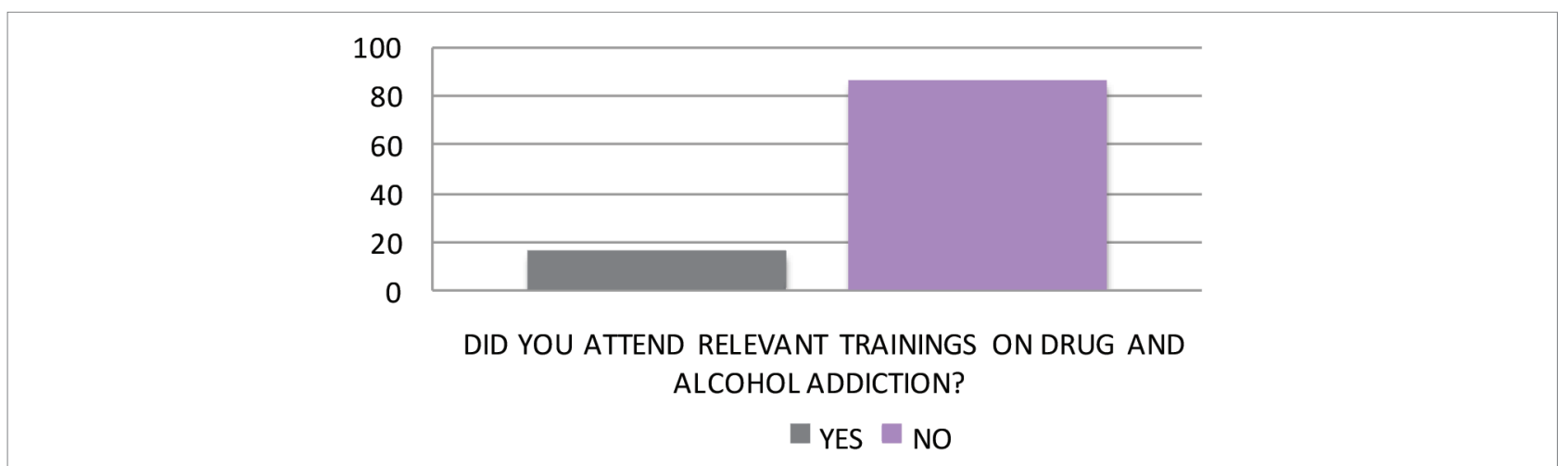

Graph 5. Data relating to question regarding relevant trainings in percentages $(\mathbf{N}=\mathbf{2 0})$

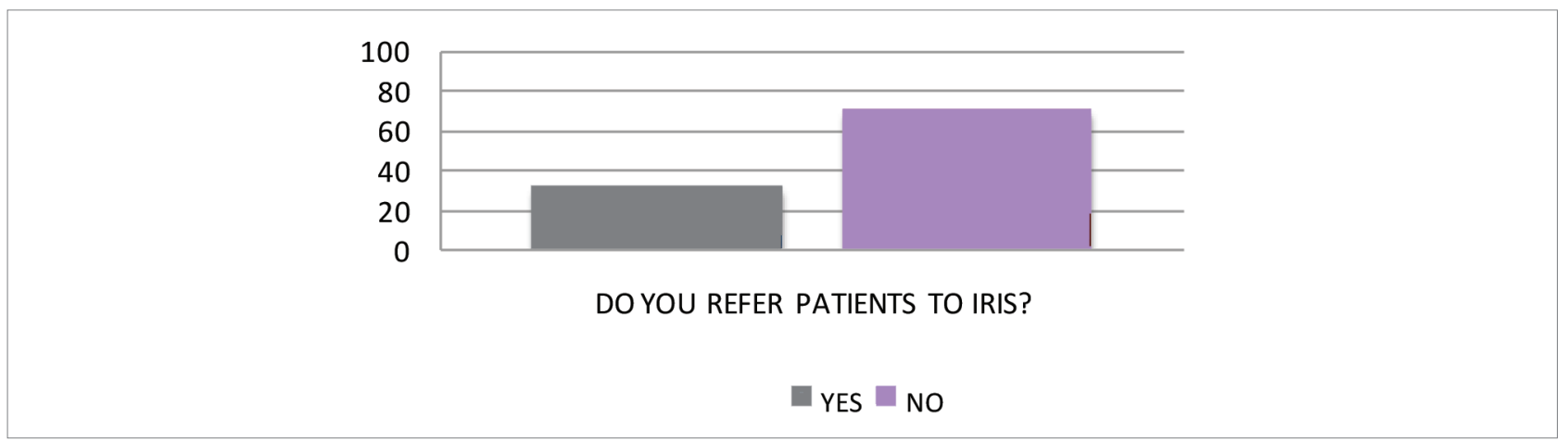

Graph 6. Data relating to question regarding refering patients to IRIS in percentages $(\mathbf{N}=20)$

Graph 7 demonstrates that $85 \%$ of the respondents believe that communication between the ward and the Drug and Alcohol Addiction Rehabilitation Centre has improved after the implementation of innovation, while $15 \%$ believe that communication has not improved even after the introduction of change.

Graph 8 demonstrates that $99 \%$ of the respondents believe that the ward currently has information packages and leaflets. Only $1 \%$ of the respondents feel that this is not the case.
Graph 9 demonstrates that $65 \%$ of the respondents attended newly organised trainings arranged by Drug and Alcohol Addiction Rehabilitation Centre, while $35 \%$ of the respondents had not yet attended such type of education.

Graph 10 demonstrates that $60 \%$ of the respondents independently refer patients to the Drug and Alcohol Addiction Rehabilitation Centre, while $40 \%$ of the respondents still do not refer patients to the same service. 


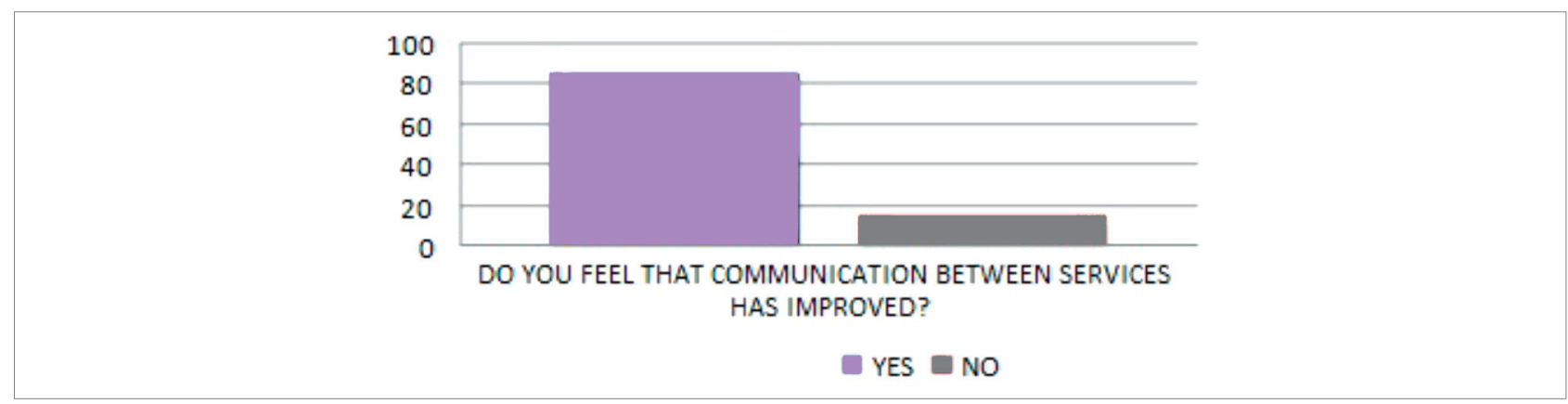

Graph 7. Data relating to the question regarding improved communication between services $(\mathrm{N}=20)$

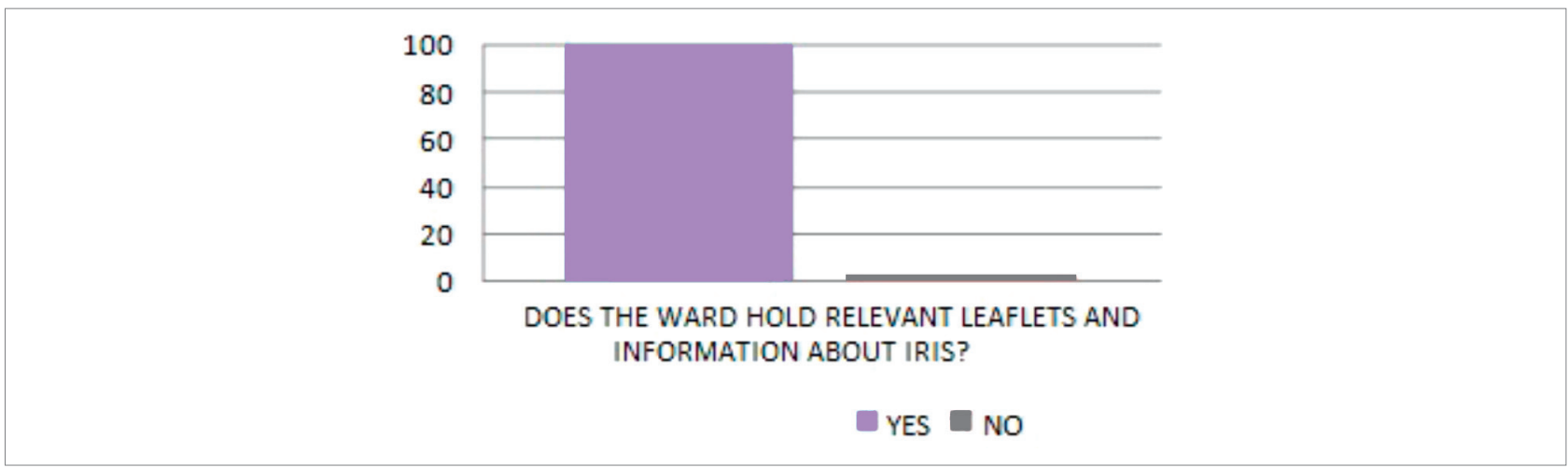

Graph 8. Data relating to the question regarding relevant signposting on the Ward in percentages $(\mathrm{N}=20)$

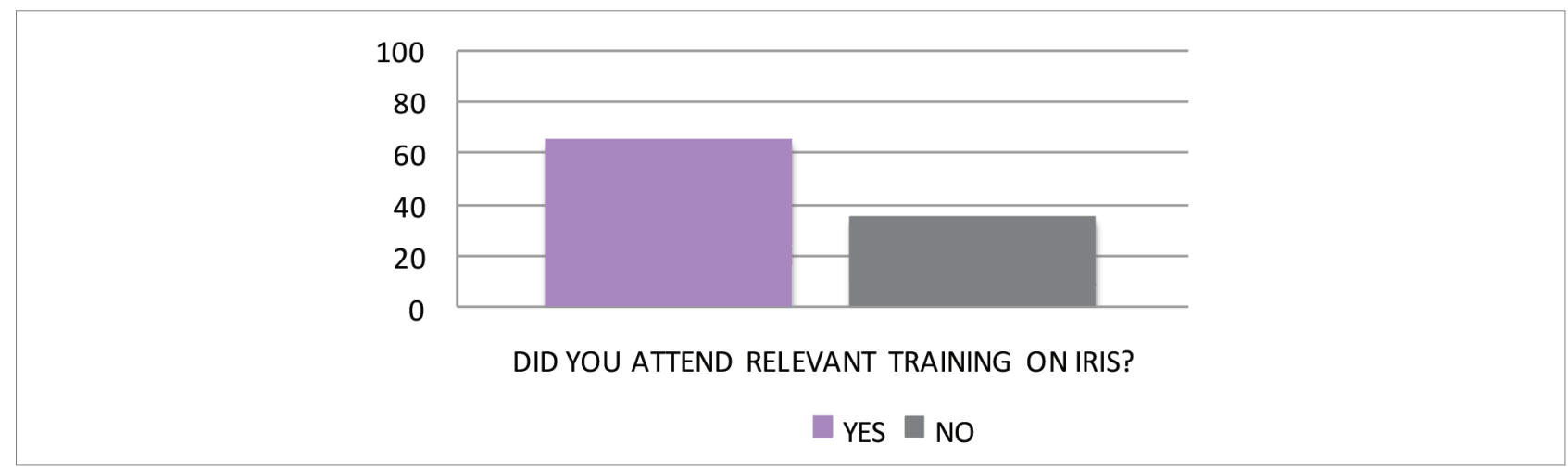

Graph 9. Data relating to the question regarding relevant training in percentages $(N=20)(N=20)$

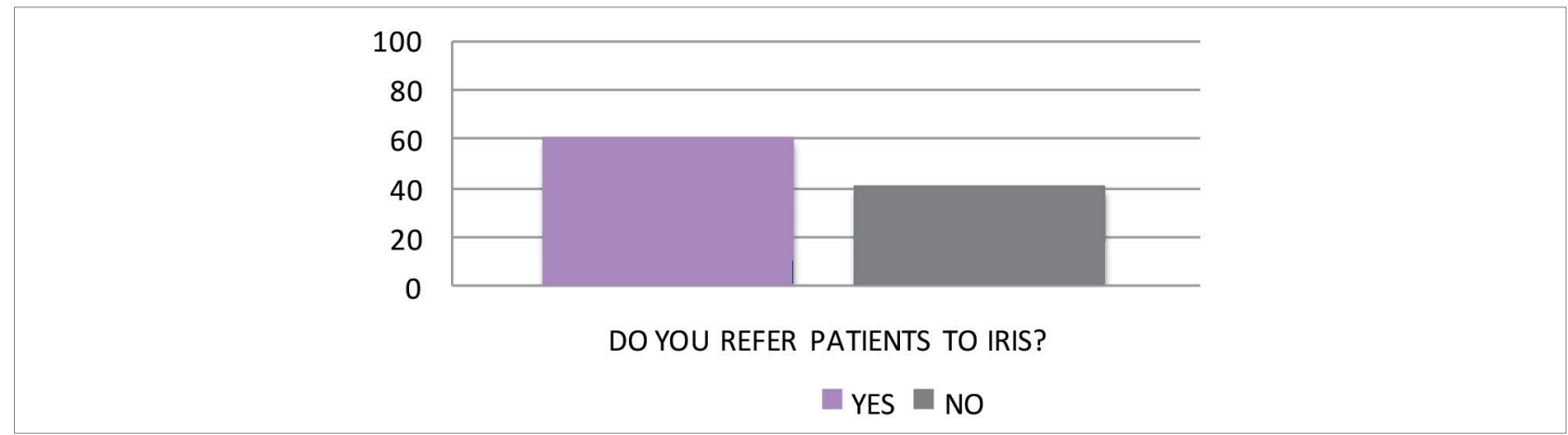

Graph 10. Data relating to the question regarding referring patients to IRIS in percentages ( $N=20$ ) 
Graph 11 demonstrates that $98 \%$ of the respondents use new referrals when referring patients, and only $2 \%$ of the respondents do not use new referrals

Graph 12 demonstrates that $90 \%$ of the respondents believe that a new poster with referring guidelines is beneficial, while $10 \%$ of the respondents feel that there is no benefit from the same poster.

\section{Comparative tabular view of the achieved changes}

Table 1 shows a comparison of the data obtained after the initial and evaluation questions processed with Fisher's exact probability test which calculated $p=0,055$. That indicates that there is no statistically significant result in the initial and evaluation answers to the above question.

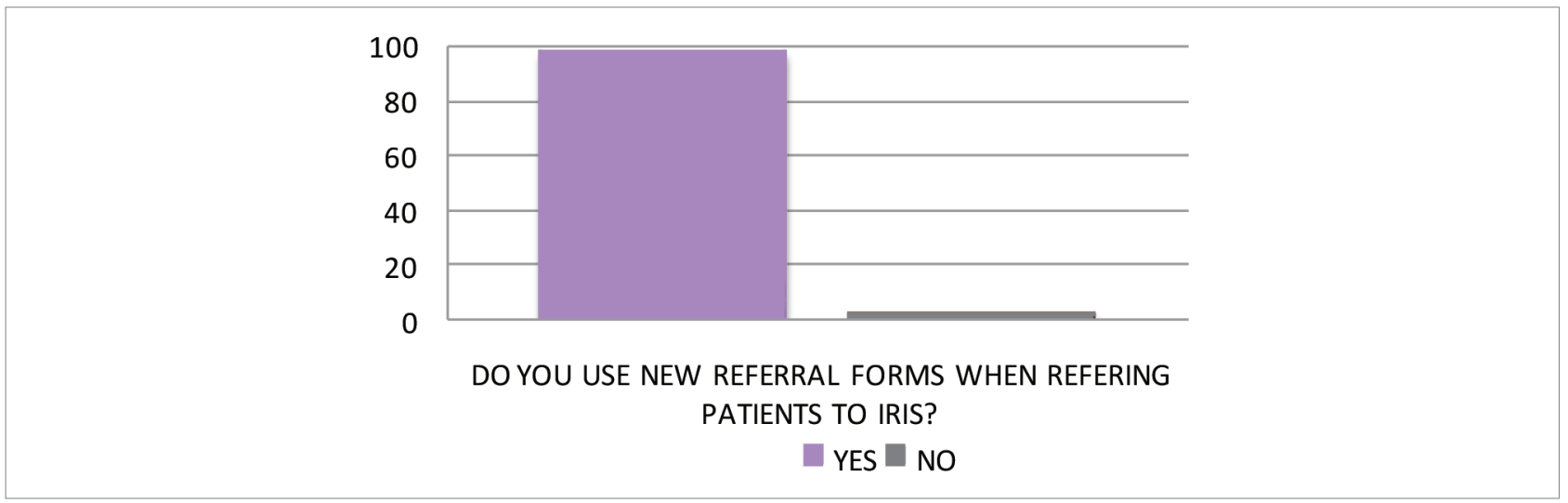

Graph 11. Data relating to the question regarding usage of new referrals in percentages $(\mathbf{N}=20)$

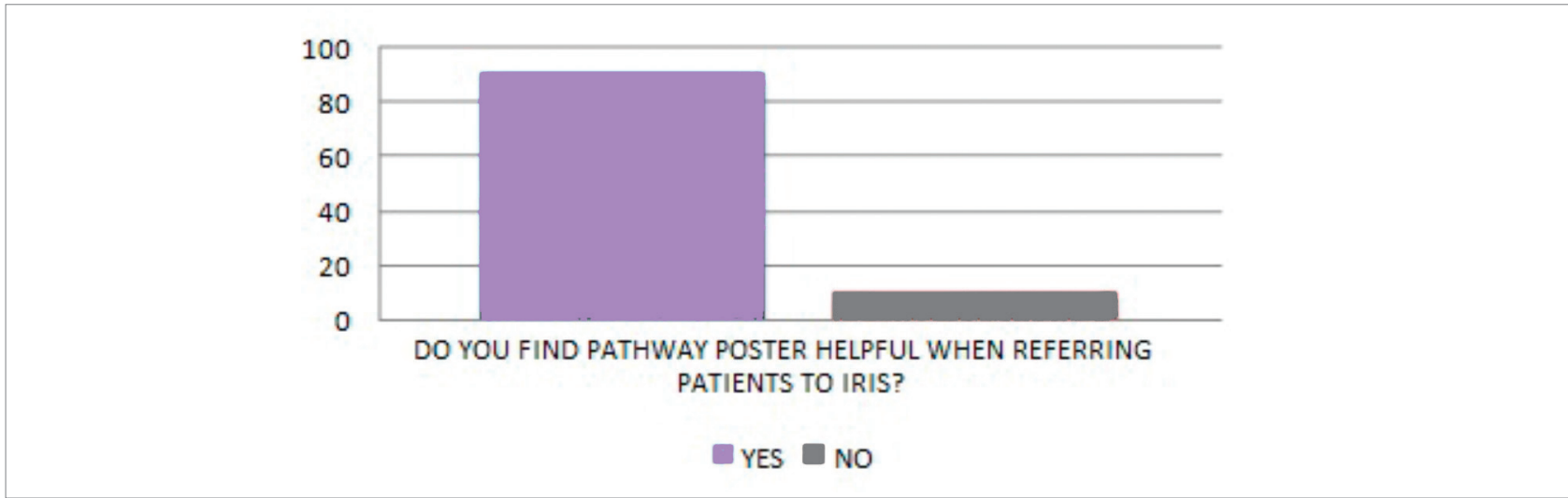

Graph 12. Data relating to the question regarding pathway poster in percentages $(\mathbf{N}=\mathbf{2 0})$

Table 1. Tabular representation of data relating to the question "Do you refer patients to community rehabilitation centre"

Do you refer patients into

Drug and Alcohol addiction

rehabilitation centre - IRIS?
YES

6

12

18
NO

Evaluation survey

TOTAL

14

1420

820

$22 \quad 40$ 


\section{Discussion}

After the initial investigation, it was clearly apparent that the ward staff lacked relevant education on drug and alcohol addiction rehabilitation centres, as $60 \%$ of the respondents were unable to name a drug and alcohol addiction rehabilitation centre available outside the hospital organisation. The questionnaire showed that $80 \%$ of the respondents were not educated about local rehabilitation centres at all. The same percentage of the respondents felt that they were not educated on drug and alcohol addiction, which leads to the question whether staff are able to conduct drug therapy and rehabilitation to patients with drug and alcohol addiction. Evidence from other research shows that "happy staff leads to happy patients" so that investment in staff and their education is of utmost importance (22). There is a possibility that the obtained result was also influenced by the level of official education among the respondents, because some of the respondent did not hold high qualification. More than half of the staff, up to $55 \%$, points to a lack of communication between the ward and IRIS, the local Drug and Alcohol Addiction Rehabilitation Centre. After these findings, it was necessary to define and implement key changes with a view to a more successful collaboration between the department and the rehabilitation centre. This result was likely affected by frequent staff changes, frequent sick leave and annual leave during the research period. It was important to establish an innovative type of communication between the two teams, which implies the creation of new ways of informing and referring patients to rehabilitation centres after discharge from the hospital, and to provide continuous, high quality education to the department staff. The changes that have been made have focused on three major categories: communication between the ward and IRIS, education on addiction and the competence to refer patients to IRIS. Application of changes must had been approved by the staff. This type of work is described by Schwartz Centre Rounds researchers who tend to allow their members to analyse problems and provide clear suggestions (13). Such a way of collaborative working has proven to increase the morale among members of the team (23). Changes require the implementation of different models and approaches in healthcare leadership. Recent research shows that most effective managers use multiple management styles at the right time. After conducting the evaluation survey, it could easily be concluded that the results obtained were different from the initial results. Implementing departmental changes has been shown to have contributed to improved communication between team members and the Centre for Drugs and Alcohol Abuse (IRIS), which can be concluded from the fact that $85 \%$ of the respondents responded positively when asked about improvements in communication. Even $65 \%$ of the respondents attended newly organized workshops and trainings by IRIS, which is of importance due to the specialty of the department. The evaluation questionnaire noted that $60 \%$ of the respondents were referring patients from the ward into the Drug and Alcohol Addiction Rehabilitation Centre (IRIS) independently, thus contributing to the creation of a new referral and setting up a poster with referring guidelines. Probably clear and simple instructions have contributed to an increase in self-confidence among staff. Although the percentage calculation showed an increase in independent patient referring, the conclusion after data processing by Fisher's exact test $(p<0.05)$ indicates that there is no statistically significant result, probably because of a small sample of respondents ( $p=$ 0.055 ). It would be beneficial to investigate this statistical problem on a bigger sample of respondents. It is clear that if a change affects an individual, it will also act on a particular action. In this case, the implementation of the change has affected the improvement of collaboration between the two teams with the aim of providing high quality therapy and care, while the impact on individuals within the teams was of paramount importance.

\section{Conclusion}

It can be concluded that leaders in health care are trying to move away from competition by implementing guidelines for collaboration. The key word in this process is integration. Leadership in health care begins when organisations and individuals cannot solve problems individually within the organisation. 
The importance of self-consciousness of personal qualities is the foundation of successful team leadership in health care. The preparation and planning of the project required collaboration with external and internal stakeholders and constant notification of all project participants on the progress of the project itself. Individual and group meetings were of great importance because they allow the retention of professional relationships and encourage further collaboration. After processing the initial and evaluation research data and after implementing changes it can be concluded that the project had an impact on patients, staff on the ward and team of therapists (physiotherapists and occupational therapists) as most of the answers in evaluation survey were positive, with answer Yes incised when asked about improved communication, relevant education and usage of new referrals and pathway poster. This project could also be extended to other departments in the hospital. Emergency and Surgical Departments are receiving patients who are addicted to drugs and alcohol every day, and early detection of such patients would have a major impact on the quality of hospital care and further rehabilitation. The project can also be combined with other currently active projects in the hospital or outside the hospital environment, although it would require staff restructuration and a new financial plan. The goals set at the beginning of the project have been achieved but the ultimate goal is to maintain the project and to develop strategies for further development within the hospital and further.

\section{References}

1. Plsek PE, Greenhalgh T. The challenge of complexity in health care. BMJ. 2001;323:625-628.

2. Tjosvold D. Team organization: an enduring competitive advantage. Chichester: Wiley.1991.

3. King T. Paradigms of Canadian nurse managers: lenses for viewing leadership and management. Can J Nurs Leadersh. 2000;13(1):15-20.

4. Collins B. New care models: emerging innovations in governance and organisational form. London: The King's Fund. Available from: www.kingsfund.org.uk/ publications/new-caremodels Accessed: 20.04.2018.

5. Drath WH, McCauley CD, Palus CJ, Van Velsor E, O'Connor PMG, McGuire JB. Direction, alignment, commitment: toward a more integrative ontology of leadership. Leadersh Q. 2008;19:635-653.

6. Rost JC. Leadership in the 21st Century. New York: Praeger; 1991.

7. Heifetz R, Laurie DL. The work of leadership. Harv Bus Rev. 1997;75(1):124-134.

8. Manchester City Council. Living longer, living better: an integrated care blueprint. Paper presented to health and wellbeing board, March. Available from: www.manchester.gov.uk/meetings/meeting/1886/health_and_wellbeing_board Accessed: 20.04.2018.

9. Wondolleck JM, Yaffee SL. Making Collaboration Work: Lessons From Innovation In Natural Resource Management. Island Press. 2000.

10. Timmins $\mathrm{N}$, Ham C. The quest for integrated health and social care: a case study in Canterbury, New Zealand. London: The King's Fund. Available from: www. kingsfund.org.uk/publications/quest-integrated-health-and-social-care Accessed: 20.04.2018.

11. West M, Lyubovnikova J, Eckert R, Denis J-L. Collective leadership for cultures of high quality health care. Journal of Organizational Effectiveness: People and Performance. 2014;1(3):240-260.

12. Adair J. Develop your leadership skills. 2nd ed. London: Kogan Page; 2013.

13. Lown BA, Rosen J, Marttila J. An agenda for improving compassionate care: a survey shows about half of patients say such care is missing. Health Aff. 2011;30(9):17721778.

14. Taylor FW. The Principles of Scientific Management. New York: Harper and Brothers; 2010.

15. Suchman AL. How we think about organizations: a complexity perspective. In: Suchman AL, Sluyter DJ, Williamson PR, editors. Leading Change in Healthcare: Transforming Organizations Using Complexity, Positive Psychology and Relationship-Centered Care. London: Radcliffe Publishing; 2011.

16. Dunbar K. How scientists think: on-line creativity and conceptual change in science. In: Ward TB, Smith SM, 
Vaid J (eds), Creative thought: an investigation of conceptual structures and processes. Washington DC: American Psychological Association; 1997.

17. Kahn MW. Etiquette based medicine. N Engl J Med. 2008;358(19):1988-9.

18. West MA. Effective teamwork: practical lessons from organisational research, 3rd ed. Oxford: Blackwell Publishing; 2012.

19. Borrill C, West MA, Shapiro D, Rees A. Team working and effectiveness in healthcare management. 2000;6(8):364-71.

20. National Advisory Group on the Safety of Patients in England. A Promise to Learn - A Commitment to Act: Improving the Safety of Patients in England. London, 2013. Available from: https://assets.publishing.ser- vice.gov.uk/government/uploads/system/uploads/ attachment_data/file/226703/Berwick_Report.pdf

21. Hawkins JD, Catalano, RF Jr. The Jossey-Bass social and behavioral science series and the Jossey-Bass education series. Communities that care: Action for drug abuse prevention. San Francisco, CA, US: JosseyBass;1992.

22. Lewin K. Group decision and social change. In: Newcomb TM and Hartley EL (eds) Readings in Social Psychology. New York: Henry Holt;1947.

23. Fillingham D, Weir B. System leadership: lessons and learning from AQuA's integrated care discovery communities. London: The King's Fund. Available from: www.kingsfund.org.uk/publications/system-leadership Accessed: 20.04.2018. 


\section{UNAPRJEĐENJE SURADNJE ODJELA GASTROENTEROLOGIJE I CENTRA ZA REHABILITACIJU OD OVISNOSTI O DROGAMA I ALKOHOLU}

\section{Sažetak}

Uvod. Potreba za razvijanjem projekta identificirana je tijekom rada $s$ multidisciplinarnim timom na gastroenterološkom odjelu u bolnici Royal Berkshire u Engleskoj, gdje je bilo očito da se zdravstveni stručnjaci suočavaju s problemima pružanja kontinuirane rehabilitacije nakon otpuštanja pacijenata ovisnika o drogama i alkoholu iz bolnice.

Cilj. Postići da svi članovi tima: radni terapeuti, fizioterapeuti, medicinske sestre i terapeutski asistenti na gastroenterološkom odjelu bolnice budu sposobni uputiti pacijente u Centar za rehabilitaciju od ovisnosti o drogama i alkoholu u zajednici IRIS te tako poboljšati suradnju s IRIS-om.

Metode. Inicijalno istraživanje provedeno je na gastroenterološkom odjelu u bolnici Royal Berkshire u Engleskoj u razdoblju između listopada i prosinca 2017., dok je evaluacijsko istraživanje provedeno u razdoblju između veljače i ožujka 2017. na uzorku od 20 ispitanika. Podaci su prikupljeni s pomoću upitnika kreiranog u svrhu ispitivanja.

Rezultati. Nakon analize rezultata evaluacijskog istraživanja uočeno je da $85 \%$ ispitanika smatra da se komunikacija među službama poboljšala, dok je čak $65 \%$ ispitanika prisustvovalo radionicama i edukacijama koje je organizirao IRIS. Statistička značajnost $(p<0,05)$ nije uočena kod upućivanja pacijenata u IRIS $(p=0,055)$, vjerojatno zbog malog uzorka ispitanika.

Zaključak. Integracija timova ključna je kod primjene smjernica koje vode prema suradnji. Implementacija promjena temeljenih na poboljšanju komunikacije, organizaciji treninga i edukaciji te upućivanju pacijenata u rehabilitacijski centar u zajednici pridonijela je porastu kompetencija članova tima na odjelu. 